\title{
UJI DAYA HAMBAT EKSTRAK SERAI WANGI (Cymbopogon nardus (L.) RendI) TERHADAP PERTUMBUHAN BAKTERI Escherichia coli ATCC 25922
}

\author{
Lutfiah Fitriani' ${ }^{1}$ Maria Tuntun², Marhamah² \\ ${ }^{1}$ Prodi Teknologi Laboratorium Medis Program Sarjana Terapan Politeknik Kesehatan \\ Tanjungkarang \\ 2Jurusan Analis Kesehatan Politeknik Kesehatan Tanjungkarang
}

[email korespondensi: lutfiahfitriani8@gmail.com]

\begin{abstract}
Inhibition Test of Citronella Extract (Cymbopogon nardus (L.) RendI) Against The Growth of Escherichia coli ATCC 25922. Escherichia coli is an opportunistic bacterium that is commonly found in the human large intestine as a normal flora. Lemongrass is a plant that can be used as traditional medicine because it contains compounds that are antibacterial. Lemongrass is known to contain alkaloids, terpenoids, saponins, flavonoids, and tannins. The purpose of this study was to determine the average diameter of the inhibition zone of citronella extract (Cymbopogon nardus $L$ Rendl) and to determine the effective concentration in inhibiting the growth of Escherichia coli ATCC 25922 bacteria, to determine the significant difference in each concentration of citronella extract. on the growth of Escherichia coli ATCC 25922. This type of research is an experiment with the Kirby Bauer Diffusion method. The concentration of citronella extract used was $10 \%, 20 \%$, $30 \%, 40 \%, 50 \%, 60 \%, 70 \%, 80 \%, 90 \%$, and $100 \%$ with 3 repetitions. The results showed that citronella extract was able to inhibit the growth of Escherichia coli ATCC 25922 at a concentration of $10 \%-100 \%$ with an average inhibition zone of $6.80 \mathrm{~mm}-$ $16.70 \mathrm{~mm}$. Analysis of the data using the One-way Anova test with the results of $\mathrm{P}=$ $0.000(P<0.05)$ indicating that the extract had an effect on the growth of Escherichia coli ATCC 25922, followed by the smallest significant difference test with $P<0.05$ indicating a significant difference for each concentration. At a concentration of $100 \%$ with a concentration of $50 \%-10 \%$, a concentration of $90 \%$ and $80 \%$ with a concentration of $40 \%-10 \%$ a concentration of $70 \%$ with a concentration of $30 \%-10 \%$ $60 \%$ and $50 \%$ concentration with $20 \%-10 \%$ concentration, and $40 \%$ concentration with $10 \%$ concentration.
\end{abstract}

Keywords : Inhibition, Escherichia coli ATCC 25922, Citronella (Cymbopogon nardus L Rendl)

Abstrak: Uji Daya Hambat Ekstrak Serai Wangi (Cymbopogon nardus (L.)
RendI) Terhadap Pertumbuhan Bakteri Escherichia coli ATCC 25922.
Escherichia coli adalah kuman oportunis yang banyak ditemukan di usus besar
manusia sebagai flora normal. Serai wangi merupakan tanaman yang dapat
dimanfaatkan sebagai obat tradisional karena memiliki kandungan senyawa yang
bersifat antibakteri. Serai wangi diketahui memiliki kandungan alkaloid, terpenoid,
saponin, flavonoid, dan tanin. Tujuan penelitian ini adalah Mengetahui daya hambat
ekstrak serai wangi (Cymbopogon nardus (L.) Rendl terhadap pertumbuhan bakteri
Escherichia coli ATCC 25922 . Jenis penelitian adalah eksperimen dengan metode Difusi
Kirby Bauer. Konsentrasi ekstrak serai wangi yang digunakan adalah $10 \%$, $20 \%$, $30 \%$,
$40 \%, 50 \%, 60 \%, 70 \%, 80 \%, 90 \%$, dan $100 \%$ dengan 3 kali pengulangan. Hasil
penelitian menunjukan bahwa ekstrak serai wangi mampu menghambat pertumbuhan
bakteri Escherichia coli ATCC 25922 pada konsentrasi $10 \%-100 \%$ dengan rerata zona 
hambat $6,80 \mathrm{~mm}$ - 16,70 mm. Analisa data menggunakan uji One-way Anova dengan hasil nilai $P=0,000 \quad(P<0,05)$ menunjukan bahwa ekstrak berpengaruh terhadap pertumbuhan bakteri Escherichia coli ATCC 25922, dilanjutkan uji beda nyata terkecil dengan $\mathrm{P}<0,05$ menunjukan adanya perbedaan yang nyata setiap konsentrasi. Pada konsentrasi $100 \%$ dengan konsentrasi $50 \%-10 \%$, konsentrasi $90 \%$ dan $80 \%$ dengan konsentrasi $40 \%-10 \%$, konsentrasi $70 \%$ dengan konsentrasi $30 \%-10 \%$, konsentrasi $60 \%$ dan $50 \%$ dengan konsentrasi $20 \%-10 \%$, dan konsentrasi $40 \%$ dengan konsentrasi $10 \%$.

Kata Kunci: Daya hambat,Escherichia coli ATCC 25922, Serai wangi (Cymbopogon nardus $L$ Rendl)

\section{PENDAHULUAN}

Penyakit infeksi merupakan jenis penyakit yang paling banyak diderita oleh penduduk negara berkembang termasuk Indonesia, salah satu penyebab penyakit infeksi adalah bakteri (Misnadiarly, 2014). Bakteri yang merupakan flora normal dalam tubuh namun dapat menyebabkan infeksi yaitu Escherichia coli. E.coli adalah kuman oportunis yang banyak ditemukan di usus besar manusia sebagai flora normal. Sifatnya unik karena dapat menyebabkan infeksi primer pada usus dan memiliki kemampuan menimbulkan infeksi pada jaringan tubuh lain diluar usus. Penyakit yang ditimbulkan akibat infeksi pada usus yaitu enteritis, gastroenteritis, colitis hemoragik, disentri basiler, demam enterik dan sebagainya dengan gejala yang menonjol ialah diare.Infeksi di luar usus yang sering ditemukan adalah sistitis, infeksi saluran kemih, infeksi saluran nafas, sepsis, dan meningitis (Karsinah, 2010).

Indonesia

mempunyai

keanekaragaman hayati salah satunya yaitu tumbuhan. Kekayaan alam berupa tumbuhan beberapa di antaranya dapat digunakan sebagai obat-obatan. Pengobatan tradisional secara turuntemurun dilakukan oleh masyarakat dengan memanfaatkan bahan yang mudah ditemukan di seluruh pelosok tanah air, berbagai jenis tumbuhan yang telah dimanfaatkan oleh masyarakat untuk mencegah maupun mengobati penyakit salah satunya yaitu serai wangi (Emelda, 2019).
Berdasarkan penelitian sebelumnya oleh Soraya dkk (2016) diketahui bahwa serai wangi mengandung alkaloid, terpenoid, saponin, flavonoid, dan tanin. Kandungan serai wangi memiliki sifat antibakteri. Flavonoid membentuk senyawa kompleks dengan protein ekstraseluler dan terlarut sehingga dapat merusak membran sel bakteri dan diikuti dengan keluarnya senyawa intraseluler sehingga dapat menyebabkan kematian sel, terpenoid dapat menghambat pertumbuhan dinding sel dengan merusak porin (protein transmembran), tanin mempunyai target pada polipeptida dinding sel sehingga akan menyebabkan pertumbuhan dan metabolisme sel terganggu, dan alkaloid dapat mengganggu pembentukan komponen peptidoglikan dinding sel bakteri dan menyebabkan sel bakteri menjadi lisis.

$$
\text { Penelitian Mahardika (2019) }
$$

tentang Efektivitas antibakteri ekstrak daun serai wangi (Cymbopogon nardus) terhadap pertumbuhan bakteri Propionibacterium acnes dengan metode difusi cakram Kirby Bauer menggunakan konsentrasi $20 \%$, 40\%, 60\%, 80\%, dan $100 \%$ didapatkan hasil bahwa ekstrak daun serai wangi(Cymbopogon nardus) konsentrasi $100 \%$ memiliki daya hambat paling besar yaitu 19,55 mm.

Penelitian lainnya dilakukan oleh Mayasari (2019) tentang aktivitas antibakteri air perasan daun serai wangi terhadap bakteri Streptococcus mutans dengan metode Difusi cakram Kirby Bauer menggunakan konsentrasi $20 \%$, $30 \%$, $40 \%$, dan $50 \%$ menunjukkan hasil 
bahwa pada konsentrasi $50 \%$ memiliki daya hambat terbesar yaitu $17,3 \mathrm{~mm}$.

Berdasarkan penelitian yang telah dilakukan, dapat diketahui bahwa serai wangi memiliki kemampuan menghambat pertumbuhan bakteri.

\section{METODE}

Jenis penelitian yang dilakukan yaitu eksperimen. Desain penelitian ini adalah Rancangan Acak Lengkap (RAL). Pengumpulan data berasal hasil pengamatan dan dokumentasi dari setiap proses penelitian. Penelitian ini dilaksanakan di Laboratorium Bakteriologi, Jurusan Analis Kesehatan, Politeknik Kesehatan Tanjungkarang. Serai wangi yang digunakan yaitu batang serai wangi (Cymbopogon nardus $L$ Rendl) varietas mahapengiri. Batang serai wangi yang digunakan dalam penelitian ini berwarna merah keunguan dengan umur 8 bulan. Batang serai wangi didapatkan dari Jalan Arjuna Dusun 5 Kecamatan Trimurjo Kabupaten Lampung Tengah.

Alat yang digunakan pada penelitian yaitu autoclave, tabung reaksi, rak tabung, oven, petridisk, ose, pinset, inkubator, lampu spirtus, blank disk, gelas ukur, erlenmeyer, karet penghisap/vacuum pump, jangka sorong, pipet ukur, lidi kapas steril, alumunium foil, rotator.

Bahan yang digunakan dalam penelitian yaitu pelarut etanol, aquadest steril, $\mathrm{NaCl} 0,85 \%$, standar Mac Farland 0,5 , Chloramphenicol $30 \mu \mathrm{g}$. Media yang digunakan dalam penelitian yaitu Mueller Hinton Agar, Nutrient Broth, Media Nutrient Agar Slant.

Analisa data menggunakan SPSS 16 dengan menggunakan uji One-way anova untuk mengetahui ekstrak serai wangi berpengaruh terhadap pertumbuhan bakteri Escherichia coli.

\section{HASIL}

Uji daya hambat ekstrak serai wangi terhadap bakteri Escherichia coli ATCC 25922, diperoleh hasil bahwa ekstrak serai wangi dengan konsentrasi $10 \%, 20 \%$, 30\%, 40\%, 505, 60\%, 70\%, $80 \%$, $90 \%$, dan $100 \%$ terbentuk zona hambat disekitar disk. Diameter zona hambat yang terbentuk adalah sebagai berikut:

Tabel 1. Diameter Zona Hambat Ekstrak Serai Wangi (Cymbopogon nardus L RendI) terhadap Bakteri Escherichia coli ATCC 25922

\begin{tabular}{|c|c|c|c|c|c|}
\hline \multirow{2}{*}{$\begin{array}{r}\text { Konsentrasi } \\
(\%)\end{array}$} & \multicolumn{3}{|c|}{$\begin{array}{l}\text { Diameter zona hambat pada } \\
\text { masing-masing pengulangan } \\
(\mathrm{mm})\end{array}$} & \multirow[t]{2}{*}{$\begin{array}{l}\text { Jumlah } \\
\text { (mm) }\end{array}$} & \multirow[t]{2}{*}{$\begin{array}{c}\text { Rata-rata } \\
(\mathrm{mm})\end{array}$} \\
\hline & $\mathrm{P} 1$ & $\mathrm{P} 2$ & P3 & & \\
\hline 10 & 6,30 & 6,60 & 7,50 & 20,40 & 6,80 \\
\hline 20 & 8,30 & 8,80 & 9,80 & 26,90 & 8,96 \\
\hline 30 & 9,90 & 9,20 & 10,80 & 29,90 & 9,96 \\
\hline 40 & 10,10 & 10,50 & 11,30 & 31,90 & 10,60 \\
\hline 50 & 11,10 & 12,60 & 14,30 & 38,00 & 12,60 \\
\hline 60 & 12,20 & 13,20 & 14,80 & 40,20 & 13,40 \\
\hline 70 & 12,40 & 13,80 & 15,80 & 42,00 & 14,00 \\
\hline 80 & 13,20 & 14,60 & 16,10 & 43,90 & 14,60 \\
\hline 90 & 14,60 & 15,30 & 16,90 & 46,80 & 15,60 \\
\hline 100 & 15,80 & 16,30 & 18,60 & 50,20 & 16,70 \\
\hline Kontrol (+) & 28,00 & 28,00 & 30,00 & 86,00 & 28,60 \\
\hline Kontrol (-) & 0 & 0 & 0 & $\begin{array}{l}00,00 \\
0\end{array}$ & $\begin{array}{l}20,00 \\
0\end{array}$ \\
\hline
\end{tabular}


Rata-rata diameter zona hambat pada konsentrasi $10 \%, 20 \%, 30 \%, 40 \%$, $50 \%, 60 \%$, 70\%, $80 \%$, 90\%, dan $100 \%$ masing-masing adalah $6,80 \mathrm{~mm}, 8,96$ $\mathrm{mm}, 9,96 \mathrm{~mm}, 10,60 \mathrm{~mm}, 12,60 \mathrm{~mm}$, $13,40 \mathrm{~mm}, 14,00 \mathrm{~mm}, 14,60 \mathrm{~mm}, 15,60$ $\mathrm{mm}$, dan $16,70 \mathrm{~mm}$. Konsentrasi terendah yang mampu menghambat pertumbuhan bakteri Escherichia coli ATCC 25922 yaitu $10 \%$ dengan rata-rata diameter zona hambat sebesar $6,80 \mathrm{~mm}$ dan konsentrasi tertinggi yang mampu menghambat yaitu $100 \%$ dengan ratarata diameter zona hambat yang terbentuk yaitu $16,70 \mathrm{~mm}$.

Berdasarkan hasil uji normalitas didapatkan nilai $p$-value $>0,05$ maka data dinyatakan berdistribusi normal. Hasil uji homogenitas didapatkan nilai $p$ value $>0,05$ maka data dinyatakan homogen atau tidak memiliki varians. Data hasil penelitian dilanjutkan ke uji One-way Anova dengan taraf kesalahan $5 \%$.

Tabel 2. Uji One-way Anova Diameter Zona Hambat Ekstrak Serai Wangi (Cymbopogon nardus L RendI) Terhadap Bakteri Escherichia coli ATCC 25922

\begin{tabular}{cccc}
\hline $\begin{array}{c}\text { Konsentrasi } \\
(\%)\end{array}$ & $\mathrm{N}$ & Rerata \pm s.b & $p$-value \\
\hline 10 & 3 & $6,80 \pm 0,62$ & \\
20 & 3 & $8,96 \pm 0,76$ & \\
30 & 3 & $9,96 \pm 0,80$ & \\
40 & 3 & $10,60 \pm 0,61$ & \\
50 & 3 & $12,60 \pm 1,60$ & \\
60 & 3 & $13,40 \pm 1,31$ & \\
70 & 3 & $14,00 \pm 1,70$ & \\
80 & 3 & $14,60 \pm 1,45$ & \\
90 & 3 & $15,60 \pm 1,17$ & \\
100 & 3 & $16,70 \pm 1,49$ & \\
\hline
\end{tabular}

Berdasarkan hasil analisa uji Oneway Anova didapatkan nilai $p$-value 0,000 $(p<0,05)$ yang berarti bahwa konsentrasi ekstrak serai wangi yang diujikan berpengaruh terhadap pertumbuhan bakteri Escherichia coli ATCC 25922 dengan terbentuknya zona hambat. Pengujian kemudian dilanjutkan dengan uji Beda Nyata Terkecil (BNT) atau Post hoc LSD (Least Significance Different) untuk menentukan kelompok yang berbeda nyata atau signifikan.

Tabel 3. Uji Post hoc LSD (Least Significance Different) ekstrak serai wangi (Cymbopogon nardus $L$ RendI) terhadap pertumbuhan bakteri Escherichia coli ATCC 25922

\begin{tabular}{lcccc}
\hline & & \multicolumn{2}{c}{ IK 95\% } & \\
\cline { 3 - 4 } & $\begin{array}{c}\text { Perbedaan } \\
\text { rerata }\end{array}$ & Minimum & Maksimum & p-value \\
\hline $100 \%$ vs $90 \%$ & 1,30 & $-2,23$ & 4,83 & 0,941 \\
$100 \%$ vs $80 \%$ & 2,26 & $-1,26$ & 5,79 & 0,445 \\
$100 \%$ vs $70 \%$ & 2,90 & $-0,63$ & 6,43 & 0,167 \\
$100 \%$ vs $60 \%$ & 3,50 & $-0,03$ & 7,03 & 0,053 \\
$100 \%$ vs $50 \%$ & $4,23 *$ & 0,70 & 7,76 & 0,011 \\
$100 \%$ vs $40 \%$ & $6,26 *$ & 2,73 & 9,79 & 0,000 \\
$100 \%$ vs 30\% & $6,93^{*}$ & 3,40 & 10,46 & 0,000 \\
$100 \%$ vs $20 \%$ & $7,93^{*}$ & 4,40 & 11,46 & 0,000 \\
$100 \%$ vs $10 \%$ & $10,10^{*}$ & 6,56 & 13,63 & 0,000
\end{tabular}




\begin{tabular}{|c|c|c|c|c|}
\hline $90 \%$ vs $80 \%$ & 0,96 & $-2,56$ & 4,49 & 0,991 \\
\hline $90 \%$ vs $70 \%$ & 1,60 & $-1,93$ & 5,13 & 0,831 \\
\hline $90 \%$ vs $60 \%$ & 2,20 & $-1,33$ & 5,73 & 0,484 \\
\hline $90 \%$ vs $50 \%$ & 2,93 & $-0,59$ & 6,46 & 0,158 \\
\hline $90 \%$ vs $40 \%$ & $4,96 *$ & 1,43 & 8,49 & 0,002 \\
\hline $90 \%$ vs $30 \%$ & $5,63^{*}$ & 2,10 & 9,16 & 0,001 \\
\hline $90 \%$ vs $20 \%$ & $6,63 *$ & 3,10 & 10,16 & 0,000 \\
\hline $90 \%$ vs $10 \%$ & $8,80^{*}$ & 5,26 & 12,33 & 0,000 \\
\hline $80 \%$ vs $70 \%$ & 0,63 & $-2,89$ & 4,16 & 1,000 \\
\hline $80 \%$ vs $60 \%$ & 1,23 & $-2,29$ & 4,76 & 0,957 \\
\hline $80 \%$ vs $50 \%$ & 1,96 & $-1,56$ & 5,49 & 0,625 \\
\hline $80 \%$ vs $40 \%$ & $4,00 *$ & 0,46 & 7,53 & 0,019 \\
\hline $80 \%$ vs $30 \%$ & $4,66 *$ & 1,13 & 8,19 & 0,004 \\
\hline $80 \%$ vs $20 \%$ & $5,66 *$ & 2,13 & 9,19 & 0,000 \\
\hline $80 \%$ vs $10 \%$ & $7,83^{*}$ & 4,30 & 11,36 & 0,000 \\
\hline $70 \%$ vs $60 \%$ & 0,60 & $-2,93$ & 4,13 & 1,000 \\
\hline $70 \%$ vs $50 \%$ & 1,33 & $-2,19$ & 4,86 & 0,932 \\
\hline $70 \%$ vs $40 \%$ & 3,36 & $-0,16$ & 6,89 & 0,070 \\
\hline $70 \%$ vs $30 \%$ & $4,03 *$ & 0,50 & 7,56 & 0,017 \\
\hline $70 \%$ vs $20 \%$ & $5,03 *$ & 1,50 & 8,56 & 0,002 \\
\hline $70 \%$ vs $10 \%$ & $7,20 *$ & 3,66 & 10,73 & 0,000 \\
\hline $60 \%$ vs $50 \%$ & 0,73 & $-2,79$ & 4,26 & 0,999 \\
\hline $60 \%$ vs $40 \%$ & 2,76 & $-0,76$ & 6,29 & 0,210 \\
\hline $60 \%$ vs $30 \%$ & 3,43 & $-0,09$ & 6,96 & 0,061 \\
\hline $60 \%$ vs $20 \%$ & $4,43 *$ & 0,90 & 7,96 & 0,007 \\
\hline $60 \%$ vs $10 \%$ & $6,60 *$ & 3,06 & 10,13 & 0,000 \\
\hline $50 \%$ vs $40 \%$ & 2,03 & $-1,49$ & 5,56 & 0,584 \\
\hline $50 \%$ vs $30 \%$ & 2,70 & $-0,83$ & 6,23 & 0,235 \\
\hline $50 \%$ vs $20 \%$ & $3,70 *$ & 0,16 & 7,23 & 0,035 \\
\hline $50 \%$ vs $10 \%$ & $5,86 *$ & 2,33 & 9,39 & 0,000 \\
\hline $40 \%$ vs $30 \%$ & 0,66 & $-2,86$ & 4,19 & 0,999 \\
\hline $40 \%$ vs $20 \%$ & 1,66 & $-1,86$ & 5,19 & 0,798 \\
\hline $40 \%$ vs $10 \%$ & $3,83 *$ & 0,30 & 7,36 & 0,027 \\
\hline $30 \%$ vs $20 \%$ & 1,00 & $-2,53$ & 4,53 & 0,989 \\
\hline $30 \%$ vs $10 \%$ & 3,16 &,- 036 & 6,69 & 0,103 \\
\hline $20 \%$ vs $10 \%$ & 2.16 & $-1,36$ & 5,69 & 0,503 \\
\hline
\end{tabular}

Hasil uji post hoc test menunjukan bahwa terdapat perbedaan yang nyata pada konsentrasi ekstrak serai wangi $100 \%$ dengan konsentrasi $50 \%$ sampai $10 \%$, konsentrasi $90 \%$ dan $80 \%$ dengan konsentrasi $\quad 40 \% \quad$ sampai $10 \%$,konsentrasi $\quad 70 \% \quad$ dengan konsentrasi $30 \%$ sampai $10 \%$, konsentrasi $60 \%$ dan $50 \%$ dengan konsentrasi $20 \%$ sampai $10 \%$, dan pada konsentrasi $40 \%$ terdapat perbedaan nyata dengan konsentrasi $10 \%$ dalam menghambat pertumbuhan bakteri Escherichia coli ATCC 25922.

\section{PEMBAHASAN}

Hasil penelitian menunjukan bahwa ekstrak serai wangi konsentrasi $10 \%$ sampai dengan $100 \%$ mampu menghambat pertumbuhan bakteri Escherichia coli ATCC 25922 yang ditandai dengan terbentuknya zona jernih di sekitar disk. Hal tersebut menunjukan bahwa semakin tinggi konsentrasi ekstrak serai wangi (Cymbopogon nardus $L$ Rendl) maka semakin besar kemampuannya dalam menghambat pertumbuhan bakteri Escherichia coli ATCC 25922, hal tersebut dikarenakan 
pada konsentrasi tertinggi tidak dilakukan pengenceran sehingga senyawa aktif yang terdapat pada konsentrasi tersebut lebih banyak daripada konsentrasi lainnya.

Rata-rata zona hambat yang terbentuk jika dibandingkan dengan kontrol positif yaitu chloramphenicol $30 \mu \mathrm{g}$ dengan rerata zona hambat $28,60 \mathrm{~mm}$ tidak menunjukan adanya konsentrasi yang efektif dalam menghambat pertumbuhan bakteri Escherichia coli ATCC 25922. Hal tersebut dikarenakan chloramphenicol merupakan antibiotik spektrum luas dan bersifat bakteriostatik. Chloramphenicol terikat dengan ribosom subunit 50s dan menghambat enzim peptidil transferase sehingga ikatan peptida tidak terbentuk pada sintesis protein sehingga sintesis protein sel bakteri menjadi terhambat (Ronal dkk, 2015).

Hasil analisis Post hoc LSD (Least Significant Different) atau Uji Beda Nyata Terkecil (BNT) didapatkan $p$-value $<0,05$ yang menunjukan adanya perbedaan nyata pada konsentrasi ekstrak serai wangi $100 \%$ dengan konsentrasi $10 \%$ sampai $50 \%$, konsentrasi $90 \%$ dan $80 \%$ dengan konsentrasi $10 \%$ sampai $40 \%$, konsentrasi $70 \%$ dengan konsentrasi $10 \%$ sampai $30 \%$, konsentrasi $60 \%$ dan $50 \%$ dengan konsentrasi $10 \%$ sampai $20 \%$, dan pada konsentrasi $40 \%$ dengan konsentrasi $10 \%$.

Zona hambat yang terbentuk menandakan bahwa ekstrak serai wangi (Cymbopogon nardus $L$ Rendl) mengandung zat antibakteri yaitu alkaloid, terpenoid, saponin, flavonoid, dan tanin yang mampu menghambat pertumbuhan bakteri, hal ini sesuai dengan yang disebutkan oleh Soraya dkk (2016), bahwa senyawa yang bersifat sebagai antibakteri yang terdapat pada serai wangi antara lain alkaloid, terpenoid, saponin, flavonoid, tanin. Flavonoid membentuk senyawa kompleks dengan protein ekstraseluler dan terlarut sehingga dapat merusak membran sel bakteri dan diikuti dengan keluarnya senyawa intraseluler sehingga dapat menyebabkan kematian sel bakteri, terpenoid dapat menghambat pertumbuhan dinding sel bakteri dengan merusak porin (protein transmembran), tanin mempunyai target pada polipeptida dinding sel bakteri sehingga akan menyebabkan pertumbuhan dan metabolisme sel bakteri terganggu, dan alkaloid dapat mengganggu pembentukan komponen peptidoglikan dinding sel bakteri dan menyebabkan sel bakteri menjadi lisis.

Metode ekstraksi yang digunakan pada penelitian ini adalah metode maserasi. Proses perendaman sampel akan berdampak pada larutnya berbagai produk metabolit sekunder akibat terjadinya perbedaan tekanan. Oleh karenanya pemilihan pelarut harus dilakukan dengan cermat sehingga dapat sesuai dengan sifat maupun karakteristik senyawa aktif dari bahan simplisia yang dilarutkan. Pelarut yang digunakan pada penelitian ini yaitu etanol 96\%. Etanol cukup dipertimbangkan sebagai cairan pengekstraksi karena tidak beracun, netral, memiliki absorpsi yang baik. Selain itu etanol dapat melarutkan alkaloid basa, minyak menguap, flavonoid, steroid, saponin, dan tanin (Emelda, 2019).

Pada penelitian ini, ekstrak serai wangi diketahui tidak efektif dalam menghambat pertumbuhan bakteri Escherichia coli ATCC 25922. Hal ini mungkin dapat disebabkan beberapa faktor yaitu pada saat pembuatan simplisia tidak didapatkan serbuk yang halus sehingga pada saat proses ekstraksi pelarut etanol belum dapat sepenuhnya menarik senyawa metabolit sekunder pada ekstrak serai wangi. Hal lain yang memungkinkan ekstrak serai wangi tidak efektif dalam menghambat pertumbuhan bakteri Escherichia coli ATCC 25922 yakni bakteri yang digunakan bersifat gram negatif. Bakteri gram negatif memiliki sistem membran ganda dimana membran plasmanya diselimuti membran luar permeabel. 
Bakteri ini mempunyai dinding sel tebal berupa peptidoglikan yang terletak diantara membran dalam dan luarnya oleh karena itu bakteri gram negatif lebih sulit dirusak menggunakan senyawa antibakteri. Menurut Pelezar dan Chan dalam Lingga, dkk (2015) menyatakan bahwa sel bakteri Gram positif mempunyai struktur yang lebih sederhana dimana dinding selnya terdiri dari lapisan peptidoglikan, hal inilah yang diduga mengakibatkan dinding sel bakteri Gram positif mudah dirusak oleh senyawa antibakteri dari pada bakteri Gram negatif.

\section{KESIMPULAN}

Berdasarkan hasil penelitian yang telah dilakukan tentang uji daya hambat ekstrak serai wangi (Cymbopogon nardus $L$ Rendl) terhadap pertumbuhan bakteri Escherichia coli ATCC 25922 dapat disimpulkan bahwa rata-rata diameter zona hambat ekstrak serai wangi yang terbentuk pada konsentrasi $10 \%=6,80$ $\mathrm{mm}, 20 \%=8,96 \mathrm{~mm}, 30 \%=9,96 \mathrm{~mm}$, $40 \%=10,60 \mathrm{~mm}, 50 \%=12,60 \mathrm{~mm}$ ， $60 \%=13,40 \mathrm{~mm}, 70 \%=14,00 \mathrm{~m}$, $80 \%=14,60 \mathrm{~mm}, 90 \%=15,60 \mathrm{~mm}$, dan $100 \%=16,70 \mathrm{~mm}$.

Ekstrak serai wangi (Cymbopogon nardus $L$ Rendl) konsentrasi 10\%-100\% tidak ada yang efektif dalam menghambat pertumbuhan bakteri Escherichia coli ATCC 25922 jika dibandingkan dengan antibiotik Chloramphenicol $30 \mu \mathrm{g}$ yang memiliki diameter zona hambat sebesar 28,60 $\mathrm{mm}$.

\section{SARAN}

Berdasarkan hasil penelitian yang didapat, jika akan dilakukan penelitian lebih lanjut disarankan untuk menggunakan spesies bakteri yang bersifat gram positif untuk mengetahui potensi senyawa aktif antibakteri serai wangi.

\section{DAFTAR PUSTAKA}

Emelda. (2019) Farmakognosi. Yogyakarta: Pustaka Baru Press.

Karsinah. (2010). Buku Ajar Mikrobiologi Kedokteran "Batang Negatif Gram" Di dalam Staf Pengajar FKUI. Mikrobiologi Kedokteran. Jakarta: Binarupa Aksara.

Lingga AR, Usman, P., Envy, R. (2015). Uji Antibakteri Ekstrak Batang Kecombrang (Nicolaia speciosa horan) Terhadap Staphylococcus aureus dan Escherichia coli.

Mayasari, U. (2020). Uji Aktivitas Antibakteri Ekstrak Daun Sereh Wangi Terhadap Pertumbuhan Bakteri Streptococcus mutans. KLOROFIL: Jurnal IImu Biologi dan Terapan 3(2).

Misnadiarly, Husjain Djajaningrat. (2014). Mikrobiologi Untuk Klinik dan Laboratorium. Jakarta: PT Rineka Cipt.

Ronal, D., Fatimawati, Budiarso. (2015). Uji Resistensi Bakteri Escherichia coli yang Diisolasi dari Plak Gigi terhadap Merkuri dan Antibiotik Klorampenikol. Jurnal e-Biomedik 3(1): 62 .

Soraya, C., Sunnati, Vivi Maulina. (2016). Efek Antibakteri Ekstrak Batang Serai Terhadap Pertumbuhan Enterococcus Faecalis, 8(2): 75-76.

Winanto, M. (2019). Uji Aktivitas Antibakteri Ekstrak Daun Serai Wangi (Cymbopogon nardus) terhadap Bakteri Propionibacterium acnes. Jurnal Biologi Lingkungan 6(1): 55-56. 